DOI: $10.17805 /$ zpu.2016.4.25

\title{
Развитие человека: энциклопедический взгляд
}

\author{
В. А. ЛУКОВ, С. В. ЛУКОВ \\ (МОСКОВСКИЙ ГУМАНИТАРНЫЙ УНИВЕРСИТЕТ)
}

Энциклопедическая статья о социальном развитии человека - одном из главных терминов социологии молодежи. Развитие молодежи идет по тем же направлениям, что и развитие человека, что и обосновывается в статье.

Ключевые слова: развитие человека; социология молодежи; энциклопедическое издание о социологии молодежи; тезаурусный подход

$\mathrm{P}$

азвитие человека - процесс продвижения человека от животного существа с принципиально подобной для всех млекопитающих организацией тела, но с относительно тяжелым мозгом, следовательно, с большим числом нейронов и более быстрой умственной реакцией на враждебные действия внешней среды до обладающего культурой существа с постепенным отдалением от других животных, противопоставлением им и, как следствие, неспособностью воспользоваться преимуществами животного мира в борьбе с внешней окружающей средой за существование. В этом процессе до определенного этапа онтогенез схож с филогенезом. Но обычный человек этого не замечает, признавая за первобытным человеком дикость, а за своим ребенком - слабость (недержание головки, неумелая речь или отсутствие речи, плач по по-

* Подготовлено при поддержке РГНФ (проект «Социология молодежи: Электронная энциклопедия», грант № 15-03-12019в).

The article was prepared with support from the Russian Foundation for the Humanities (Project title: "Sociology of Youth: An Electronic Encyclopedia", Grant No. 15-03-12019в). 
воду недовольства и т. д.). Аишь в особых ситуациях (инсульт, старческое слабоумие, травма черепа и т. д.) становится очевидной связь нарушений нормального течения филогенеза с ранними его стадиями, что не находит отражения в энциклопедической литературе, посвященной человеку, этапу его молодости, прежде всего. Молодость обладает уникальным свойством: биологически филогенез завершен, но культурная составляющая развития человека находится в стадии освоения, причем одни индивиды преуспели в этом больше, чем другие. Это свойство по большей части не отражено в энциклопедиях.

Таков, в частности, философско-энциклопедический словарь «Человек» - издание, подготовленное Институтом человека РАН в 2000 г. под руководством акад. РАН И. Т. Фролова (1929-1999) незадолго до его смерти (Человек, 2000). Словарь содержит более 400 статей. И хотя в нем нет статьи «Молодежь» или «Молодость», ряд статей соответствует предмету социологии молодежи, а именно: «Воспитание» (статья А. А. Аеонтьева), «Воспитание социальное» (статья А. В. Мудрика), «Половое созревание» (статья С. $\Lambda$. Кузнецова) и др.

Раннее издание энциклопедии «Человек» (Человек, 1900) было, во-первых, переводным, во-вторых, ориентированным на характерное для того времени понимание психологии в ее связях со строением тела и развитием человеческих рас. Принципиально новый подход, заложенный Институтом человека и его основателем и директором И.Т.Фроловым, состоял в использовании междисциплинарности как основы знаний о человеке и его мире.

В последние десятилетия широкое распространение получили представления о путях развития человека в духе доктрины трансгуманизма, которая порывает с просвещенческой идеей естественного человека, облагороженного образованием, и ратует за отказ от естественного человека в пользу преодолевающего его природные свойства постчеловека, образование которого трансформируется в новые формы коммуникаций. В своих разработках теоретико-методологических основ биосоциологии молодежи (Иуков, 2011, 2012аb) мы стремимся учитывать это обстоятельство как интеллектуальный проект, который все ближе к реализации на практике.

В энциклопедиях есть основания придерживаться техники, описываемой понятием «тезаурусный эскиз».

Под тезаурусным әскизом имется в виду описание действительности, как оно складывается в тезаурусе. Этот процесс, ориентационный по своей природе, происходит в средних зонах тезауруса. На данный процесс влияет, с одной стороны, картина мира, отличающаяся высокой прочностью, малой динамикой, концентрированностью, отсутствием детализации, а с другой, периферийная информация - хаотичная, подвижная, не обобщенная, прошедшая лишь первый отсев в мембранах тезауруса. Тезаурусный әскиз представляет дескриптивную версию человека и мира, в отличие от картины мира, призванной дать их (человека и мира) образную концепцию. Тезаурусный эскиз может быть персональным, а также и групповым, хотя групповой тезаурус в меньшей степени предполагает его представление через описание, так как он призван закрепить главные ориентиры, лишенные присутствующей в эскизе детализации.

Электронная энциклопедия «Социология молодежи» (www.soc-mol.ru) сконструирована с применением тезаурусного эскиза. В энциклопедии выделены как общие проблемы молодости (социализация, идентификация и др.), так и сиюминутные, преходящие формы развития молодежного движения, которые выражают стремление 
молодежи к выявлению ее социальной субъектности в той мере, в какой ей удалось ее освоить. Таким образом, свойства молодости перенесены на общую проблематику развития человека.

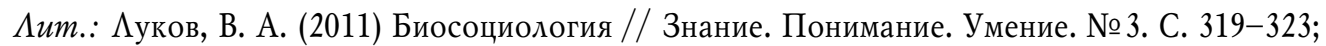
Ауков, В. А. (2012а) Биосоциология молодежи и будущее гражданского общества // Знание. Понимание. Умение. № 1. С. 13-19; Ауков, В. А. (2012b) Биосоциология молодежи: экспертные оценки изменений в новых поколениях // Знание. Понимание. Умение. № 3. С. 146-156; Человек (1900) / И. Ранке; пер. с нем. Т. 1-2. СПб. : Просвещение. 758 с.; Человек (2000): Филос.-энциклопедич. словарь / под общ. ред. И. Т. Фролова. М. : Наука. 516 с.

Аата поступления: 11.09.2016 г.

\section{HUMAN DEVELOPMENT: AN ENCYCLOPEDIC VIEW \\ V. A. LUKOV, S. V. LUKOV \\ (MOSCOW UNIVERSITY FOR THE HUMANITIES)}

This is an encyclopedia entry on human social development as one of the key terms of sociology of youth. We show that youth development follows in the same directions as human development in general.

Keywords: human development; sociology of youth; Sociology of Youth: An Electronic Encyclopedia; thesaurus approach

\section{REFERENCES}

Lukov, V. A. (2011) Biosotsiologiia. Znanie. Ponimanie. Umenie, no. 3, pp. 319-323. (In Russ.)

Lukov, V. A. (2012a) Biosotsiologiia molodezhi i budushchee grazhdanskogo obshchestva. Znanie. Ponimanie. Umenie, no. 1, pp. 13-19. (In Russ.)

Lukov, V. A. (2012b) Biosotsiologiia molodezhi: ekspertnye otsenki izmenenii v novykh pokoleniiakh. Znanie. Ponimanie. Umenie, no. 3, pp. 146-156. (In Russ.)

Chelovek (1900), comp. J. Ranke. In 2 vol. St. Petersburg, Prosveshchenie. 758 p. (In Russ.)

Chelovek (2000): Filos.-entsiklopedich. slovar', ed. I. T. Frolov. Moscow, Nauka. 516 p. (In Russ.)

Submission date: 11.09.2016.

Иуков Валерий Андреевич - доктор философских наук, профессор, директор Института фундаментальных и прикладных исследований Московского гуманитарного университета, заслуженный деятель науки Российской Федерации. Адрес: 111395, Россия, г. Москва, ул. Юности, д. 5. Тел.: +7 (499) 374-75-95. Эл. адрес: v-lukov@list.ru

Ауков Сергей Валерьевич - кандидат социологических наук, магистр социальной работы (Германия), заместитель директора Центра социологии молодежи Института фундаментальных и прикладных исследований Московского гуманитарного университета. Адрес: 111395, Россия, Москва, ул. Юности, д. 5. Тел.: +7 (499) 374-75-95. Эл. адреc: sv-lukov@rambler.ru

Lukov Valery Andreevich, Doctor of Philosophy, Professor, Director, Institute of Fundamental and Applied Studies, Moscow University for the Humanities; Honored Scientist of the Russian Federation. Postal address: 5 Yunosti St., Moscow, Russian Federation 111395. Tel.: +7 (499) 374-75-95. E-mail:v-lukov@list.ru

Lukov Sergey Valerievich, Candidate of Sociology, Master of Social Work (Germany), Deputy director, Center for Sociology of Youth, Institute of Fundamental and Applied Studies, Moscow University for the Humanities. Postal address: 5 Yunosti St., 111395 Moscow, Russian Federation. Tel.: +7 (499)374-75-95. E-mail: sv-lukov@rambler.ru 